\title{
Near-Death Experience by Proxy: A Case Study
}

\author{
Cherie Sutherland, B.A. \\ University of New South Wales
}

ABSTRACT: A recent interview with a 34-year-old man, currently serving a life sentence for murder, revealed a remarkable case of "near-death experience by proxy." The phenomenological features of the experience unfolded typically, with some slight variation in content. The immediate drastic changes in attitude and belief following the experience are described.

In a study of the sociological implications of the near-death experience (NDE), I have been interviewing near-death experiencers throughout the eastern states of Australia. Along with this major sample, I have also sought to interview two smaller samples of (1) those who have been close to death, or clinically dead, yet have not had, or could not remember, a near-death experience, and (2) those who have had an experience that had many features similar to a near-death experience, but who were not actually close to death. It was in the latter context that I interviewed the 34-year-old man whom I will call Robert for the purposes of this paper.

I conducted the interview with Robert in the office of the prison psychologist, who also remained present, at a maximum security prison in a provincial center of New South Wales. Robert presented as a tall, well-built, good-looking man, open-faced, clear-eyed, and affable.

Ms. Sutherland was formerly a lecturer in the Department of Social Work, University of Sydney. She is currently a doctoral student in the School of Sociology, University of New South Wales. Requests for reprints should be sent to Ms. Sutherland at the School of Sociology, University of New South Wales, P.O. Box 1, Kensington, NSW 2033, Australia. 
We talked for more than three hours, ninety minutes of which was tape recorded.

\section{Background}

Robert was born in 1955 of Australian parents. When he was four, his father was involved in a car accident, sustained brain damage, and subsequently was in and out of psychiatric hospitals for many years, and became unpredictably, uncontrollably violent. Robert's childhood was continuously disrupted. At the age of 11 his mother took him away and left him with his brother and sister-in-law. At one stage, while running away, he was injured in a hit-and-run accident. He left school in his third year of high school.

At age 15 a friend tried to get him out of that environment by taking him to New Zealand, where he stayed for about three years; he came back to Australia, went back to New Zealand again, got into trouble and spent 12 months in jail. On release from jail he came back to Australia and joined the army. He was in the army for nine months when he committed an offense. He then spent four years in a maximum security prison before escaping. He was out for nine months, shot a man, and one month later was recaptured. Several months later he had his "near-death experience."

\section{Circumstances of the Experience}

The following is taken directly from the taped record of the interview.

I was sitting in my cell one night, by myself. I had been reading several times a letter that had been sent to me by my then de facto [wife] that day, which was asking me to examine the reasons why I really shot this person. Was it because of childhood sort of emotional things, lots of anger, confused, no sense of purpose or responsibility?

And so I was thinking about all of these things. And I started to feel some feelings of guilt and I started to go through some sort of change in state of mind. I started experiencing some sort of mental feeling and I had a very clear impression that I could face this mental experience that was happening. It was as though a door was opening up and I was able to walk through it or turn my back and walk away from it. I didn't really understand what was happening. I just knew that it was going to be a profound sort of thing. I decided to go with it. 
I had some sort of intuitive impression that it would be showing me something. I knew not what. But I decided to go with it.

I experienced a sort of tingling, a mental sort of tingling and I started to lose perception of my surroundings. I was sort of in that state that I knew that I could go with it or back away and come out of it. I wasn't under drugs or anything like that. It was as though a voice was in me saying, "Just watch and learn." So I went with the feeling and it just totally absorbed me. I just lost consciousness. I was probably in the experience, at a guess, three to four minutes. And after the experience I was still in the same position, with my eyes still open, that I was in before I went into it. Yet I'd had no perception of where I was at all; I was totally involved in the experience.

I put myself basically into the position of this person when I shot him. Basically, he'd dug a bit of a ditch in the ground. He didn't know what it was for. And after he'd dug it I was questioning him. I had a gun on him; I pulled a gun on him, and I said, "I want to talk to you about some things that I've been told you said about me," and . . . after that questioning I shot him.

I put myself-I imagined myself-in his position. So I mentally was imaging myself in this bit of a ditch and, trying to reproduce, put myself through the anguish and terror that I put him through. And I don't know whether "he" shot me or "something" shot me.

\section{The Experience}

I remember I was looking at myself, like an out-of-body experience where you watch yourself, and I saw myself being shot and saw and felt myself going through these writhings of the body, in some sort of pain, the death throes I suppose it was. Yet I wasn't actually feeling it, as in pain. I was aware that my body was losing strength while I was actually viewing the body from outside. I felt there was losing strength and losing of a certain type of consciousness. . .

And then I started losing sight of that scene and I started going into another state of consciousness. It was almost as though I was drifting away from that ... and as I was drifting away from it, it was fading from my view and some other sort of dimension was taking its place. The ... uh ... it's a bit difficult to describe, but it's more like an intuitive understanding of things that was happening, not so much voices talking to me or anything like that. And I was seeing things, I was going through various states of feelings and certain unsureties. I just knew that I was traveling through various dimensions of consciousness.

The first clear vision that I saw was one of bubbles, a universe filled with bubbles. And within these bubbles, well, initially I saw two nongender-type beings, smooth-skinned, something like you'd see in an alien-type movie, little gentle creatures with smooth skin and nongender, big eyes, you know, things you want to take home and pat. 
I sort of recognized one of them as being myself and another of these beings was in a bubble some distance away. And we were both pressing against the bubbles towards each other and I had a very strong sense of yearning to be one with that other bubble and that other being. And we were drawing closer and closer together and there was this definite sense of yearning. ...

I had this feeling that this yearning was what that hell-like state is. To go through some sort of sense of anguish of disunity, and the yearning to become one, was happening in this sort of microcosmic sense between us two. And yet there was the macrocosmic sense that the other bubbles were all going through that same sort of process. There was just this state of tension and yearning that existed universally but it was somehow trying to resolve itself. We came-the bubbles came-together and touched, but there was this definite resistance there.

I came away from that. I started going through some other perceptions then that the time was just not quite right. I can't recall the other bubble drifting away, but it was; again like with the body, my consciousness was going through into some other dimension and that vision was sort of left, faded away. And then, there were various other things sort of flooding in, having to do with oneness and love, and universality and all of these things, and energy resolving itself, purpose.

Then the next clear sight that I had was, I saw a tiny speck, you could say below you if you like; it's a bit difficult. But I saw this tiny speck in the distance. It was as though everything had started to blacken and I felt as though I was falling towards it, like a parachutist jumping at night. And I was just hurtling towards it. I could almost feel like a rush, not of wind, but of a soft, warm sort of feeling, you know, as I was moving towards this little speck, which was getting bigger and bigger and bigger. It was as though the speck was light, but it wasn't a blinding light at all.

I was just focusing on this and it came to the size of about a ten-cent piece held at arm's length and I recognized it as a fetus. It was as though the fetus was in a spotlight. And I had a conscious impression that it was a three-month-old fetus.... And I sort of, again very quickly, I felt as though I were entering this fetus, but I don't recall there actually being that connection. It was as though once again I lost sight of it even though it was just milliseconds away from impact. It's just gone. And perhaps it happened so quickly that I impacted.

And I came back to consciousness and myself [snaps fingers] just like that. And there was just this powerful sensation of oneness and love, and purpose and direction, and compared to what I knew before, a greater understanding, because I knew basically nothing before that experience: total transition from what seems total unconsciousness to total consciousness. And I just laughed and cried at the same time. It affected me so greatly, that experience.

I died in a sense in that experience. I died to the past because when I had that experience, when I came out of it, my perception was so different to what I had before. Basically my attitudes towards many 


\begin{abstract}
things, my understandings of many things was changed. It happened instantly. It was a total transformation, or I could say a vast transformation, in an instant. Within those three to four minutes I was transforming, and it wasn't till I came out of the experience that I realized that I was a different person. So I suppose in one sense, to use a cliché, it was a "born-again" type of experience. I felt a totally different person and I believe I was a totally different person.
\end{abstract}

Robert maintained that he was "almost totally unprepared" for what happened to him during his experience. He had never read any books about the near-death experience, and the only book with anything vaguely mystical about it that he had read, he related wryly, was Zen and the Art of Motorcycle Maintenance (Pirsig, 1974). He telephoned his de facto wife two days later, when he was next allowed to make a phone call, and told her what had happened. "She was very happy," he related. "She had some difficulty appreciating it fully, but she understood that something profound had happened, had fairly changed me and put me onto what's called 'the path."

\title{
Aftereffects
}

Robert began reading widely, looking at some of the mystical teachings "trying to look for the unity in things rather than the differences." Today he reports that he is still "working through the dross aspects of various organizations, religious philosophies, whatever, to try and find the golden mean that runs through them all." About six months before I met him, he came across a serious article in a newspaper about the near-death experience (NDE). He said, "I was just buzzing as I was reading it, because I could relate to everything that was being said."

During the interview I asked Robert the same questions that I have asked my entire sample of near-death experiencers, interested to know whether his responses would be similar or different. These questions covered a wide range, from changes in attitude toward self, to attitudes toward current social movements. I asked about beliefs in and experience of psychic phenomena, attitude toward religion and spirituality, and attitude toward death.

Robert no longer has any fear of death. He said, "I don't have any fear of death at all, from that first moment." He stated that he was not a religious or spiritual person before his experience, but now considers that he is developing a spirituality that he never had before. "It is a state of growth. I am definitely heading in a direction which would be 
termed spiritual, for sure." Meditation has become a central focus for his spiritual growth: "I know now that one must meditate."

He did not identify himself with any particular religion before his experience: "I sort of had inklings that the answer was something greater than all of them put together." From the time of his experience he read a lot of Zen meditation books and nine months later, when transferred to another jail, he had the opportunity to join a Siddha Yoga group whose members came into the jail to teach meditation. At the same time he joined Ananda Marga, whose members were also holding meditation groups. He became the prison coordinator for the Siddha Yoga Ashram program in that jail, but also remained a member of Ananda Marga. He said that he found no conflict between the two since he was only interested in the "essence" of what they both had to offer.

When he was moved to another jail, he found there was no Siddha Yoga program yet the Ananda Marga continued to visit, so his association with Siddha Yoga faded. He stated that he found appealing the social issue commitment of Ananda Marga and continued as a member of that group for four years. However, as he said:

In that time I was evolving and looking not to the organization as the answer to everything. ... I've always been trying to work in a positive way with the resources that I had, being aware of all the limitations in them and myself, getting some help along the way.

Then another group, the Esoteric School of Science, sent a member into the jail, also to teach meditation. That person later became Robert's wife, more than three years ago. He now teaches meditation in the jail himself and counsels fellow inmates who are new on the path.

Before his experience he already believed that psychic phenomena occurred, having had a few experiences himself since childhood. $\mathrm{He}$ had never attached any great significance to any of this, other than the feeling that one day he would be shown something: "I've always held onto that belief. After that experience, that was why I was crying with relief, because I knew that that was what I had been waiting for."

For Robert there had been a marked increase in the incidence and clarity of apparent psychic phenomena since the experience. These include clairvoyance, clairaudience, precognition, and a feeling of greater rapport with ostensible beings who operate on subtler realms of consciousness, from whom he takes guidance and teaching: "I believe those feelings come through as an assistance in teaching, as one would help a younger brother or sister: a bit of a nudge here, a bit of a 
whack on the back of the head there." He added, "It's just a natural part of life today.... You might call it an expanded awareness."

Robert has had one out-of-body experience in the years since his experience, and that occurred during meditation. He noted that occurrences of déjà $v u$ had been more frequent and more vivid prior to the experience. When asked about "supernatural rescues," he remarked that he believed that in some way everything was a test. He said:

\begin{abstract}
I believe that if you hold the truth, if you go through the lesson and keep the heart in the right place, that positive things will lend themselves to happen. Not as any reward or seeking that as a reward, but to me that's simply the way things are. I've seen it manifest in different ways when I've been true to myself. I've seen it happen enough to have faith that it's the proper way to go.
\end{abstract}

Although always somewhat aware of his dreams, Robert is more aware of them since the experience. In addition, they have changed somewhat in content and clarity. He now quite often has what he calls "teaching dreams." These involve either himself teaching others or other beings giving him specific teachings. These teachings are very clear when he wakes up, and he has made it a practice to write them down: "They are always of great benefit."

When asked about changes in attitude toward himself, he answered:

I was the second person I learned to love. The first person I really learned to love was the person I shot. That was the most profound feeling after [the experience]: that I had a greater understanding of what love was. So all of that love went to that person as having helped me experience that, showing me in some way some aspect of truth. And then I felt a rush of love for myself, because I wasn't very pleased with who I was or what I was up to that time. And just a sense of purpose and direction finally in my life. I started to understand who I was and what my part in everything else was. And that feeling of love then spread out to others, and to my de facto [wife] and to our little child that was growing away inside her. And sort of spreading out... yes.

His sense of self-worth increased. He said, "I don't hate myself the way I used to. I have greater respect for myself; but I sort of transmit that respect for myself as being what is a deeper love and respect for something greater than I."

When asked about change in motivation he said the experience

motivated me in a more positive way and it gave me things to be motivated about. Before that I didn't have much direction, I couldn't 
get sort of excited about anything. I was filled up with negativity and confusion, negativity due to confusion. After that I had direction, I had purpose, and I was very motivated.

Robert's interests also changed, as already suggested.

My interests and my priorities [since the experience] have always been what you might term spiritual because that to me is the reality. The external physical plane expressions are only practical things for us to go through to better assist one in being able to do the other. It's always been my priority [since the experience]. It's always been very difficult for me to explain that-my attitude towards that and the mechanics of it-to people who determine whether I get out of jail or not. It's always difficult to try and share with them my perception of who and what I am. My highest priority is spiritual. No one will change that.

On what Robert calls "a more mundane level," last year he very successfully completed the first year of a Social Welfare course as an external student at a nearby tertiary institution. Due to the introduction of a new tertiary education fee this year he can no longer afford to continue this course. He does hope, if ever released, to complete it at some later date and to work as a volunteer welfare worker. In its place he is now taking a course in welding with the aim of being able to support himself financially if he is released.

There have also been many changes in the way Robert cares for his physical well-being in daily life since his experience. The experience gave him

a very great motivation to be vegetarian. I had a greater understanding then of not killing higher evolved life forms. I try to keep in mind certain principles of not harming, or harming the least possible. I have a greater appreciation for my diet, so I have stuck with it ever since, for the last eight years.

He practices Hatha Yoga and meditates daily. He opposes smoking, drinking, and drugs of any kind, whereas prior to arrest he had been a heavy drinker, which was as he said "a contributing factor to being stupid."

Over the last eight years he has been involved with a number of outside organizations, such as Community Aid Abroad, the Eritrean Relief Association, and the Ethiopian Relief Project, for which he fasted and ran raffles within the prison to raise funds. He is most concerned with ignorance of any kind: 
Anything that is negative, harmful to the environment, harmful to our growth and development as human beings, anything that stops us from growing together I see as ignorance. So I guess I am interested in a number of social issues of varying types ... such as the peace movement, Greenpeace, worldwide environmental issues.

He supports the rights of women, homosexuals, racial and ethnic minorities, and children: "I'm supportive of people's basic human rights. [In any area of ignorance] I try and make myself educated with the limited resources I have."

When asked what he considers to be the most significant change to come about since the experience, Robert answered:

Probably finding out who I was, getting a better idea, I should say, of who I was. And I suppose getting a direction in life with that understanding. I gained a lot more answers to things which had been such gaps in my life. Before that I was just causing pain to myself and pain to others. But ... no more, no more.

\section{Discussion}

As is clear from the above, Robert's "near-death experience by proxy" led to immediate, far-reaching changes that now, eight years later, are well established in his lifestyle. The pattern of changes evident in Robert's case is strikingly similar to the changes in attitudes and beliefs of the more than 50 near-death experiencers in my sample to date. My sample of other people who have had an NDE-like experience but who were not close to death is too small at this stage to draw any definite conclusions. However, so far I have not found the level of aftereffects experienced by Robert in those cases.

The implications for the individual, in this case Robert, are obviously immense. He no longer has a fear of death and he has had a marked increase in psychic sensitivities leading to a general expanded awareness. He has a powerful need to learn and to love, a commitment to spiritual growth, and a sensitivity to the needs of others. He now has something to be motivated about, a real purpose in life, and within the limitations of his circumstances, he is living it.

For society, the implications of this case are no less significant. Most of the above mentioned changes in turn have had an impact on Robert's immediate social environment. Within the prison community he now teaches meditation and counsels fellow inmates. He prepares his vegetarian meals in a group kitchen and is willing to share his rea- 
sons. At times he fasts to raise funds for international aid organizations. He is eager to show a video about the near-death experience for those who are interested, and to talk about it afterwards with any inmates who care to follow up. He has discussed his experience with the prison psychologist, who now is also interested.

Robert has also had a significant impact on the wider community. For example, through his participation as a Social Welfare student last year, he has a number of acquaintances at that tertiary institution. Since our interview, he has been in contact with the dean of the School of Social Sciences, who has agreed to arrange a showing of the neardeath experience video for the Social Sciences students. Through his association with groups such as Community Aid Abroad and Greenpeace, he has used his loving attitude in a practical way in an even wider concern.

In another sense a case such as Robert's has implications for the criminal justice system. The recidivism rate worldwide is extremely high. It has been shown time and again that incarceration is not the way to produce "good citizens." As a multiple offender, a past escapee from custody, and a murderer, Robert's chances of being released or even sent to a minimum security prison are slim.

Nevertheless, I was informed that in the eight years since his experience all reports on him in all aspects of prison life have been highly favorable. Yet he has been advised that the very episode that has brought about this change cannot be mentioned to the prison administration because of their lack of understanding about such matters. It seems that the image our society has of murderers does not permit such a spiritual awakening.

Yet in his most recent book, Raymond Moody related the case of a man who was "a con artist and an outright criminal who had done everything from bilking widows to running drugs," who after a neardeath experience now has "an honest and helpful profession" (188, $p$. 29). Charles Flynn wrote of the case of "an organized crime operative" who had been involved in gambling, prostitution, and violence. Yet since his NDE that man "makes a modest living as a member of one of the helping professions and does a great deal of volunteer work" (1986, p. 41). Robert's near-death experience by proxy appears to have had the same effect.

For therapists, Robert's case could suggest something of a challenge. It is well known now that visualization techniques are very powerful tools for healing on a physical level. Robert appears to have used this very method to bring about a spiritual healing. Obviously the emotional tie to the man he shot was a facilitating factor in his case. 
Placing himself in the position of his victim must have created a powerful situation.

Nevertheless it could be the case that such a technique could be used in similar circumstances. A commitment on the part of the client to work with such an event would be an obvious prerequisite. Apart from murderers in prison, other groups for whom this technique could be useful are Vietnam veterans and suicide attempters. If showing suicide attempters literature about NDEs has a positive effect (Moody, 1988), how much more powerful would be an actual experience if it could be induced in this way?

\section{References}

Flynn, C.P. (1986). After the beyond: Human transformation and the near-death experience. Englewood Cliffs, NJ: Prentice-Hall.

Moody, R.A., Jr. (1988). The light beyond. New York, NY: Bantam.

Pirsig, R.M. (1974). Zen and the art of motorcycle maintenance: $A n$ inquiry into values. New York, NY: Morrow. 